\title{
Four new species of the jumping spiders from the Philippines, with description of the male of Pbintella piatensis Barrion et Litsinger, 1995 (Araneae: Salticidae)
}

\author{
Четыре новых вида пауков-скакунчиков из Филиппин, \\ с описанием самца Pbintella piatensis Barrion et Litsinger, 1995 \\ (Araneae: Salticidae)
}

\author{
Mario Freudenschuss ${ }^{1}$, Michael Seiter ${ }^{2 *}$ \\ Марио Фрейденщюс ${ }^{1}$, Майкл Зайтер ${ }^{2 *}$
}

${ }^{1}$ Gutenhofnerstraße 13, 4300 St. Valentin, Austria.
${ }^{2 *}$ Group of Arthropod Ecology and Behavior, Division of Plant Protection, Department of Crop Sciences, University of Natural Resources
and Life Sciences, Peter Jordan Strasse 82, 1190 Vienna, Austria.
* Corresponding author: michael.seiter@boku.ac.at

KEY WORDS: Arachnida, taxonomy, new species and records, South East Asia.

КЛЮЧЕВЫЕ СЛОВА: Arachnida, таксономия, новые виды и находки, Юго-Восточная Азия.

ABSTRACT. Four new species of the jumping spiders from the Philippines are diagnosed, illustrated and described: Agorius marieae sp.n. (†), Epidelaxia maurerae sp.n. (+), Lepidemathis luisae sp.n. $\left(\sigma^{7}\right)$ and Phaeacius hampi sp.n. (†). The unknown male of Phintella piatensis Barrion et Litsinger, 1995 is described for the first time. Additional faunistic records for 15 salticid species from the Philippines are presented as well.

РЕЗЮМЕ. Диагностированы, проиллюстрированы и описаны четыре новых вида пауков-скакунчиков из Филиппин: Agorius marieae sp.n. (†), Epidelaxia maurerae sp.n. (+), Lepidemathis luisae sp.n. $\left(\sigma^{7}\right)$ и Phaeacius hampi sp.n. (†). Впервые описан неизвестный самец Phintella piatensis Barrion et Litsinger, 1995. Также приведены дополнительные фаунистические находки для 15 видов сальтицид с Филиппин.

\section{Introduction}

The salticid spider fauna of the Philippines remains poorly known. Despite the very interesting biogeographical landscape of the archipelago, only some 110 species of the Salticidae have been recorded from there to date [Metzner, 2015; WSC, 2015]. Till 1890, almost 50 species had been described and this still represents the majority of the known salticid fauna of the Philippines [Simon, 1877; Karsch, 1880]. In the following 50 years only 20 new species were added [Banks, 1930]. The subsequent bulk of new species (almost 40) was added between 1950 and 2000. Afterwards the archipelago has been virtually neglected with regards to spiders, with more new species of the jumping spi- ders being lately described by Barrion, Litsinger [1995].

In the present paper four new salticid species are described. All specimens were collected by the authors during the 2012 field trip to the Philippines. A new species of the genus Phaeacius Simon, 1900 belongs to the subfamily Spartaeinae and represents a group of rather atypical salticids, of which some species are web-invaders preying on other spiders [Forster, 1982; Jastrzębski, 1997]. We are also describing two new species from the salticid genera Agorius Thorell, 1877 and Lepidemathis Simon, 1903 (both in the subfamily Salticinae sensu Maddison [2015]). The fourth of the newly described salticid species has been tentatively placed in the genus Epidelaxia Simon, 1902 of the subfamily Salticinae (incertae sedis, sensu Maddision [2015]), but its correct generic placement requires further studies when the missing sex $\left(O^{7}\right)$ has been collected. It is also likely that this new species could be a member of the genus Capidava Simon, 1902 of the subfamily Freyinae [sensu Edwards, 2015], or belongs to the subfamily Salticinae. Some authors would even argue that the species might belong to either Habrocestoides Prószyński, 1992 or Chinattus Logunov, 1999 in the subfamily Hasariinae, but this idea is not supported by its elongated body shape and particularly by the conformation of the spermathecae [cf. Logunov, 1999]. Nevertheless, in our opinion, it is important to describe this new species despite its provisional generic assignment in order to highlight the importance of this interesting finding and to stress upon the shortage of taxonomic knowledge of Salticidae of the Philippines. Finally, the male of Phintella piatensis Barrion et Litsinger, 1995 is described hereinafter for the first time [cf. Barrion, Litsinger, 1995]. 


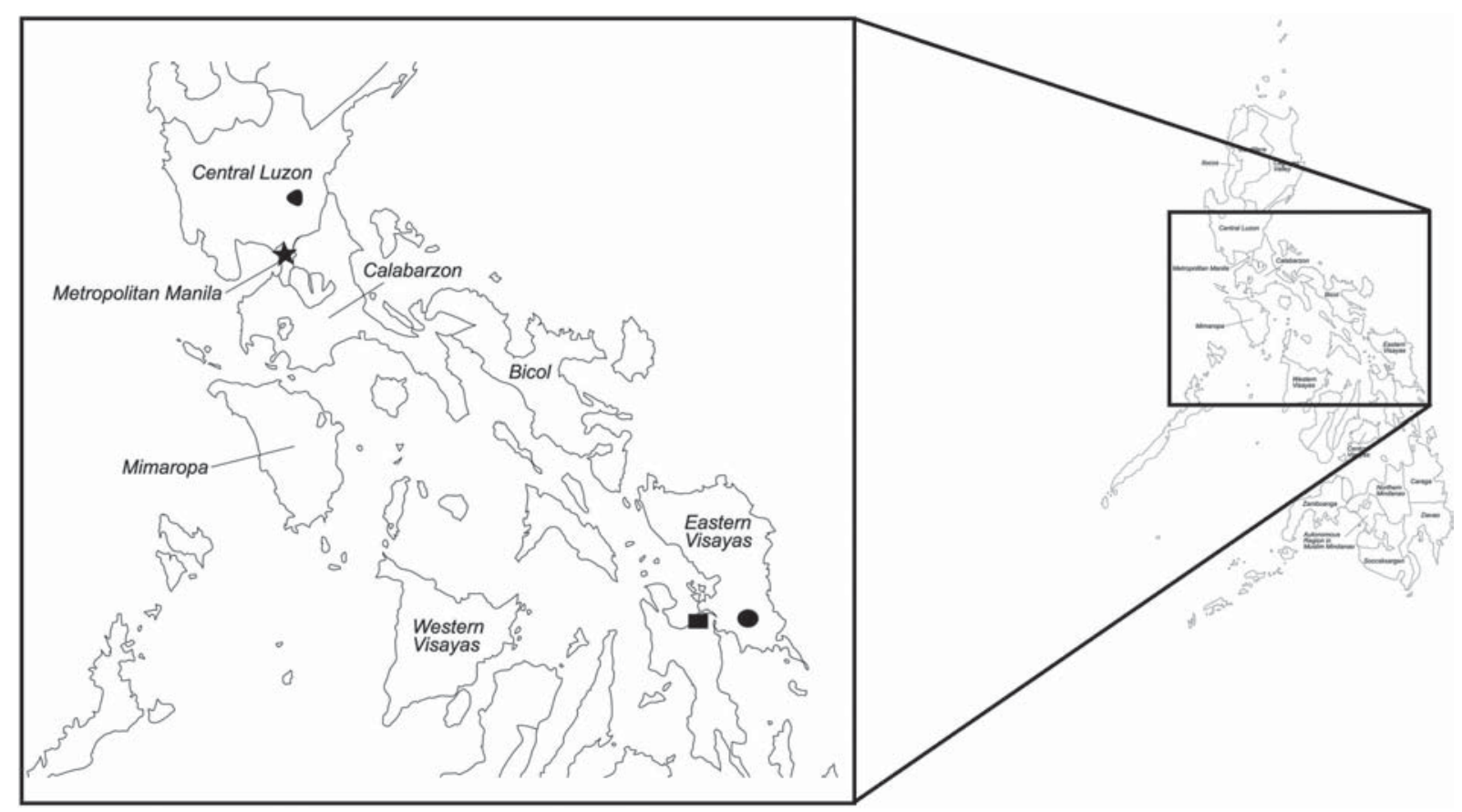

Map. Collecting localities of the newly described species and the first records for the Philippines (C) d-maps.com): star (Hasarius adansoni), rectangle (Agoruis marieae sp.n.), circle (Epidelaxia maurerae sp.n., Lepidemathis luisae sp.n.) and triangle (Phaeacius hampi sp.n., Menemerus bivittatus, Phintella piatensis).

Карта. Места находок новоописанных видов и первые указания для Филиппин (С) d-maps.com): звезда (Hasarius adansoni), прямоугольник (Agoruis marieae sp.n.), круг (Epidelaxia maurerae sp.n., Lepidemathis luisae sp.n.) и треугольник (Phaeacius hampi sp.n., Menemerus bivittatus, Phintella piatensis).

The aims of the present paper are: (1) to describe four new salticid spider species and the yet unknown male of $P$. piatensis, and (2) to provide new faunistic records with comments for other 15 species from the Philippines (see Table).

\section{Material and methods}

The studied specimens were hand-collected from different islands of the Philippines and from various localities and habitats (for details see below under each species' account and in the Table; Map). All specimens were preserved in $70 \%$ ethyl alcohol, then studied and measured under a stereomicroscope (Leica M205A) equipped with a Leica DFC420 camera. Habitus photos were made with a Canon EOS 400D equipped with a $105 \mathrm{~mm}$ lens incl. Sigma 1:2.8 macro objective with additional baffle rings. Photographs of the copulatory organs were taken with a Canon EOS 400D camera equipped with a flash unit Canon Speedlite 430 EX II connected to a Nikon SMZ 1000 stereomicroscope by a photoadapter LM_Scope TUST38C. All digital images were processed using Adobe Photoshop ${ }^{\circledR} 8.0$ to optimize their contrast.

The nomenclature follows WSC [2015]. For the measurements the system adopted is that used by Metzner [1999]; all measurements are in mm. Description of colour patterns is based on alcohol-preserved specimens. The specimens were identified on the basis of the descriptions and illustrations provided in the online databases by Prószyñski [2015] and Metzner [2015]. The phylogenetic classification follows Maddison [2015].

All the type and voucher specimens are deposited in the Natural History Museum Vienna (Curator: Mag. Christoph Hörweg), abbreviated in the following text as NHMW. The following abbreviations are used in the text: ALE - anterior lateral eyes; AME - anterior median eyes; FE - femur; ME - metatarsus; PA patella; PLE - posterior lateral eyes; TA - tarsus; TI - tibia; TR - trochanter.

\section{Taxonomic survey}

Genus Agorius Thorell, 1877

Agorius: Thorell [1877]; Simon [1901a,b, 1903b]; Badcock [1918]; Prószyński [1968, 2009a]; Edmunds, Prószyński [2001]; Szüts [2003].

REMARKS. The genus Agorius was originally described from Sulawesi (Celebes) and is known from various countries of SE Asia. It includes ten described species [Metzner, 2015; WSC, 2015], with the type species being $A$. gracilipes Thorell, 1877. Some of the Agorius species exhibit numerous similarities with Synagelides Bösenberg et Strand, 1906 [Edmunds, Prószyński, 2001; Szüts, 2003; Prószyński, 2009a]. The following characters are shared in all species of the genus: a very long PA I, which is as long as FE I, the 


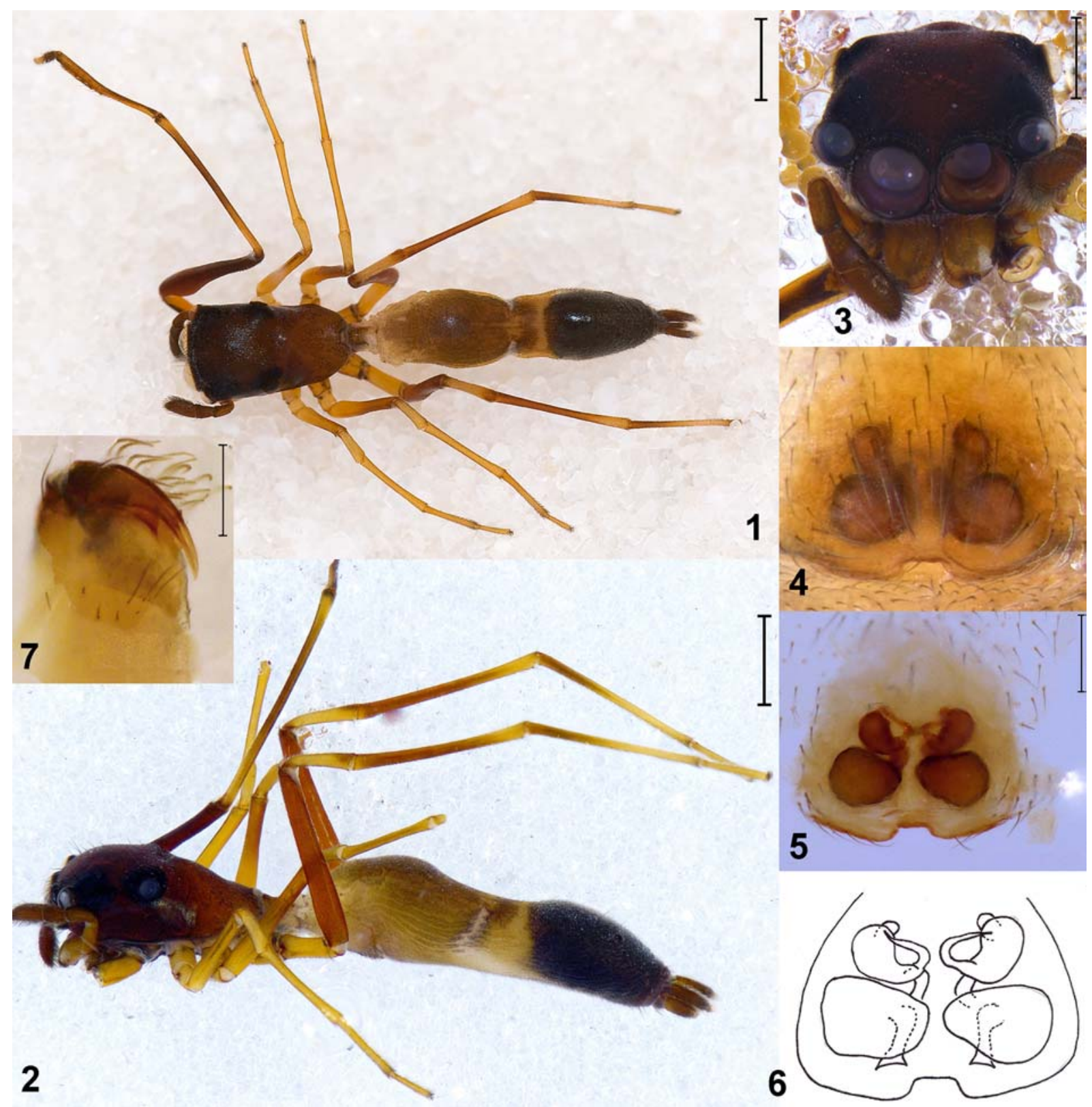

Figs 1-7: Agorius marieae sp.n., 9 holotype: 1 - habitus, dorsal view; 2 - ditto, lateral view; 3 - ditto, frontal view; 4 - epigyne, ventral view; 5-6 - spermathecae, dorsal view; 7 - right chelicera, ventral view. Scale bars: $1 \mathrm{~mm}(1-2), 0.5 \mathrm{~mm}(3), 0.1 \mathrm{~mm}(4-7)$.

Рис. 1-7: Agorius marieae sp.n., ㅇ голотип: 1 - габитус, вид сверху; 2 - тоже, вид сбоку; 3 - тоже, вид спереди; 4 - эпигина, вид сверху; 5-6 - сперматека, вид сверху; 7 - правая хелицера, вид снизу. Масштаб: 1 мм (1-2), 0,5 мм (3), 0,1 мм (4-7).

concentration of spines on the ventro-distal part of TI I and usually very long spines on ME I. It is believed that this appendages are raptorial and used for hunting. Another important diagnostic character, which is more pronounced in the males, is the thin and elongated abdomen constricted in the middle. Only males have a sclerotized scutum on the dorsum. The conformation of copulatory organs varies and in some species is similar to that of the genus Synagelides [Edmunds, Prószyński, 2001; Szüts, 2003; Prószyński, 2009a].

Only four Agorius species are known from both sexes: A . baloghi Szüts, 2003, A. constrictus Simon,
1903, A. kerinci Prószyński, 2009 and A. lindu Prószyński, 2009 [Prószyński, 2009]; four species are known from the males only, and two from the females.

\section{Agorius marieae sp.n.}

Figs 1-7.

TYPES. Holotype + (NHMW, 21901) from the Philippines, Leyte, Busay Falls Resort $\left(11^{\circ} 24.506^{\prime} \mathrm{N}, 124^{\circ} 50.871^{\prime} \mathrm{E}\right), 60 \mathrm{~m}$ a.s.l., hand collecting, 23.04.2012.

ETYMOLOGY. The species is dedicated to the first author's (MF) daugther Marie Freudenschuss. 
DIAGNOSIS. A. marieae sp.n. is most similar to $A$. kerinci and $A$. lindu [cf. Prószyński, 2009], but can be readily distinguished from these and all other Agorius species by the conformation of the spermathecae having distinctive proportions and shape (Figs 5-6). The spermathecal chamber is almost oval, as long as the diagonal postero-median part of the spermathecae. All other Agorius species have the bean-shaped spermathecae. Finally, with the total body length of $6.83 \mathrm{~mm}$, it is the largest known species of the genus.

DESCRIPTION. MALE unknown.

FEMALE (holotype). A medium sized species, with the body length of $6.83 \mathrm{~mm}$. The cephalic region of the prosoma dark brown and granulated, the eye region blackish. The thoracal region light brown and smooth. The abdomen is constricted in the middle, its anterior half yellowish brown, posterior half blackish, and the constriction area yellowish. Ventrally, the anterior half more cream-coloured. Spinnerets long and light brown. Leg I with FE and the distal half of TI brownish. Leg II and III yellowish, FE III with some brown in its distal part. Leg IV with brownish FE, the proximal part of TI and ME. ME IV about as long as TI I. Sternum lanceshaped, yellowish brown. Labium yellowish brown, outer part of maxillae dark brown, inner part contrastingly lighter (yellowish, Figs 1-3, 7). Epigyne small and flat, without conspicuous structures on the epigynal plate, but with two indistinct depressions at its posterior edge. Copulatory openings are situated close to each other, along the median line (visible as indistinct shadows). The posterior edge of the epigyne with a small, rectangular pocket (Fig. 4). The spermathecal chamber as long as the diagonal postero-median part of the spermathecae. Spermathecae consists of two chambers connected by a short benting duct; the posterior chamber larger and almost oval, the anterior one kidneyshaped and arranged along the median line of the epigyne. The well-developed benting duct arises from the larger posterior chamber and is as long as the anterior chamber itself. The latter seems to be split by a 'pore', which actually is the fetilization duct (Figs 5-6).

Measurements. Distance between ALEs 1.55; distance between AME to PLE 1.43; distance between PLEs 1.49; prosoma: median length 2.62, width 1.46; abdomen median length 4.21 , width 1.20 ; posterior diameter of eyes 0.53 ; pedipalps: TR 0.21 , FE 0.46 , PA 0.28, TI 0.21, TA 0.54; Leg I: TR 0.90, FE 2.61, PA 2.78, TI 1.86, ME 0.39, TA 0.41; Leg II: TR 0.23, FE 1.48, PA 0.42, TI 1.02, ME 1.02, TA 0.58; Leg III: TR 0.32 , FE 1.26, PA 0.48, TI 1.38, ME 0.94, TA 0.47; Leg IV: TR 0.64, FE 1.28, PA 0.60, TI 1.86, ME 1.49 , TA 0.71 .

DISTRIBUTION. The type locality (Busay Falls Resort in Leyte, the Philippines) only (Fig. 35).

HABITAT. Busay Falls Resort in Leyte is a leisure center close to the resort. The area is located at a small hill covered with the secondary rainforest. There are several trails in this area and the specimen was found next to a small river running in a rocky area with several sunny spots.

\section{Genus Epidelaxia Simon, 1902}

Epidelaxia: Simon [1902, 1903a]; Prószyński [1987].

REMARKS. The genus Epidelaxia Simon, 1902 contains only three Sri Lankan species [Metzner, 2015; WSC, 2015], with its type species E. albocruciata Simon, 1902 known from Colombo, Sri Lanka. Two species - E. albocruciata and E. obscura Simon, 1902 - remain known from the males only, and $E$. albostellata Simon, 1902 is known from both sexes. The original description by Simon [1902] is inadequate, whereas Prószyński [1987: 22] presented the drawings of the copulatory organs of $E$. albostellata only. Furthermore, the female of E. obscura is listed in the WSC [2015] by mistake, as only the male from Kandy, Sri Lanka, is currently known (cf. Simon [1902: 368]). Due to the lack of reliable data, we are tentatively placing the new species in the genus Epidelaxia of the subfamily Salticinae (incertae sedis, sensu Maddison [2015]), until the missing sex $\left(\sigma^{7}\right)$ and more species of the genus are discovered and their true phylogenetic relationship is resolved.

\section{Epidelaxia maurerae sp.n.}

Figs 8-13.

TYPES. Holotype 9 (NHMW, 21902) from the Philippines, Samar $\left(11^{\circ} 14.141^{\prime} \mathrm{N}, 125^{\circ} 15.900^{\prime} \mathrm{E}\right), 287 \mathrm{~m}$ a.s.l., hand collecting, 21.04.2012.

ETYMOLOGY. The species epithet is a patronym in honor of Lisa Maurer (Vienna, Austria), who supported the second author (MS) during his field work.

DIAGNOSIS. E. maurerae sp.n. can be distinguished from E. albostellata by the central triangular depression delimited by a pair of diagonal atrial lips and the triangular posterior extension with a small, circular structure visible through the integument.

DESCRIPTION. MALE unknown.

FEMALE (holotype). A medium sized species, with the body length of $7.03 \mathrm{~mm}$. The cephalic region of the prosoma dorsally brown, with a median light band running from the fovea to the petioles and being anteriorly wider than posteriorly. Black rings around the eyes; the eyes are also surrounded by black scales, AMEs are surrounded by red scales (Figs 8-10). Chelicera brownish, pluridentate, with a saw-like blade of teeth on its retromargin (Fig. 14). Labium and maxillae brown. Sternum light brown. Abdomen elongated, anteriorly light violet, each lateral side with a bright whitish stripe, dorsum with two whitish stripes and a cardiac mark (Fig. 8). Spinnerets uniformly dark brown. Legs orange, leg I stronger than the others, ME I with two spines, TI I with three spines, TA orange, with bright black stripes. Epigyne with a triangular posterior extension having a characteristic circular structure visible through the integument (Fig. 11), which seems to be only known in Habrocestoides species from SE Asia, Thiratoscirtus species from Africa and the genus Chinattus known from southern regions of the Palaearctic Region, SE Asia and N America. Huge diagonal sclerotized atrial lips cover the entrances to copulatory openings. The lips delimit a 


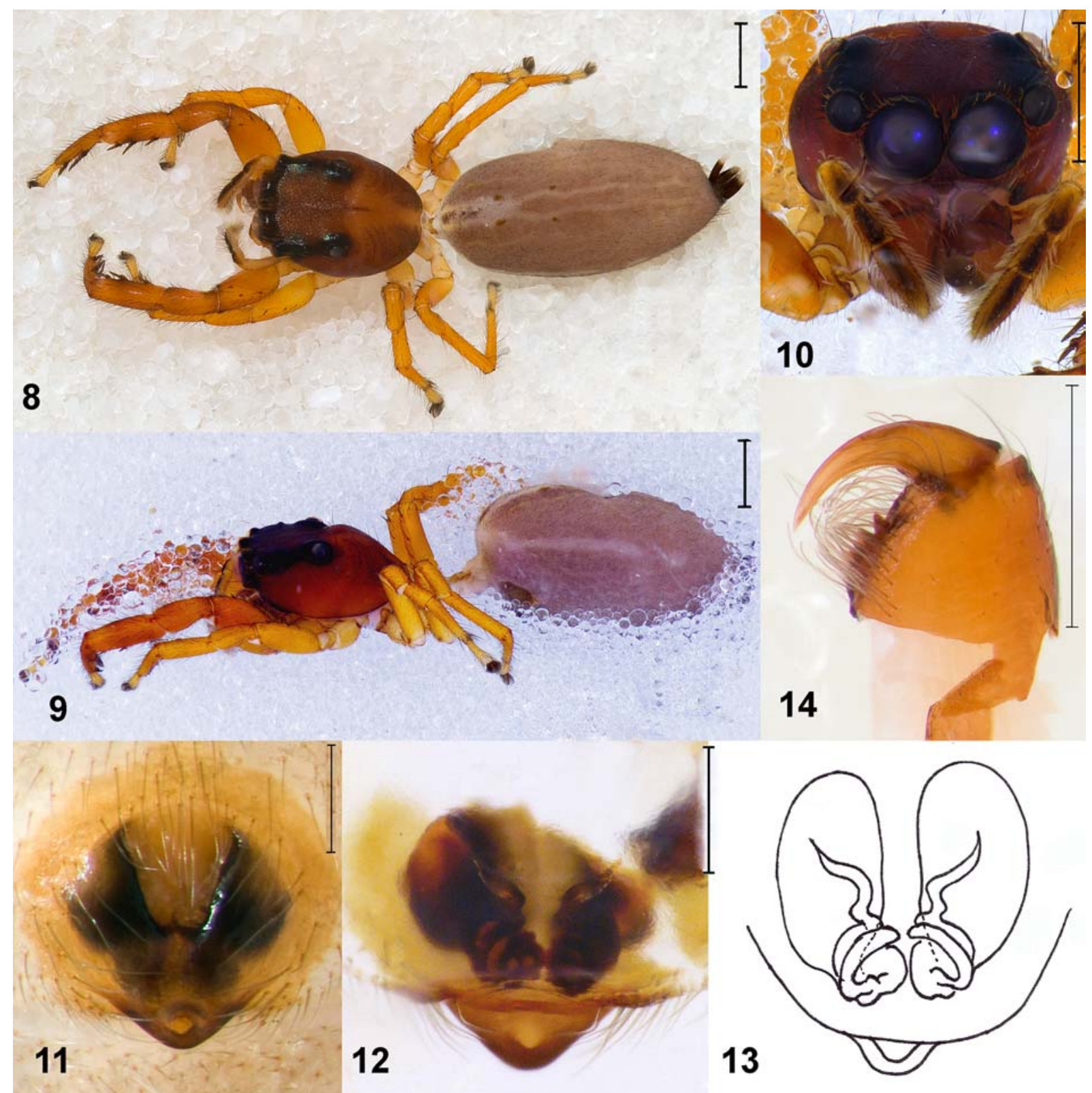

Figs 8-14. Epidelaxia maurerae sp.n., + holotype: 8 - habitus, dorsal view; 9 - ditto, lateral view; 10 - ditto, frontal view; 11 epigyne, ventral view; $12-13$ - spermathecae, dorsal view; 14 - left chelicera, ventral view. Scale bars: $1 \mathrm{~mm}(8-10), 0.5 \mathrm{~mm}$ (14), 0.1 $\mathrm{mm}(11-13)$.

Рис. 8-14. Epidelaxia maurerae sp.n., о голотип: 8 - габитус, вид сверху; 9 - тоже, вид сбоку; 10 - тоже, вид спереди; 11 эпигина, вид снизу; 12-13 - сперматека, вид сверху; 14 - левая хелицера, вид снизу. Масштаб: 1 мм (8-10), 0,5 мм (14), 0,1 мм $(11-13)$

central, triangular depression. Lips sclerotized and blackish, with their edges deeply black; the internal structures are translucent and gray. Insemination ducts are coiled and markedly sclerotized, with prominent triangular fertilization ducts (Figs. 12-13).

Measurements. Distance between ALEs 1.71; distance between AME to PLE 1.19; distance between PLEs 1.64; prosoma: median length 2.74, width 2.05; abdomen median length 4.29 , width 2.05 ; posterior diameter of eyes 0.55 ; pedipalps: TR 0.22 , FE 0.58 , PA 0.38, TI 0.33, TA 0.48; Leg I: TR 0.30, FE 1.20,
PA 0.68, TI 1.28, ME 0.85, TA 0.45; Leg II: TR 0.24, FE 1.33, PA 0.51, TI 0.91, ME 0.71, TA 0.45; Leg III: TR 0.30, FE 1.71, PA 0.38, TI 0.60, ME 0.79, TA 0.44; Leg IV: TR 0.43, FE 0.94, PA 0.69, TI 1.16, ME 1.06 , TA 0.57 .

DISTRIBUTION. The type locality (Samar, the Philippines) only (Fig. 35).

HABITAT. The collecting locality was near a road running within the rainforest situated along the coastal line and without high vegetation. The holotype was collected from the ground in the exposed sunny grassland. 

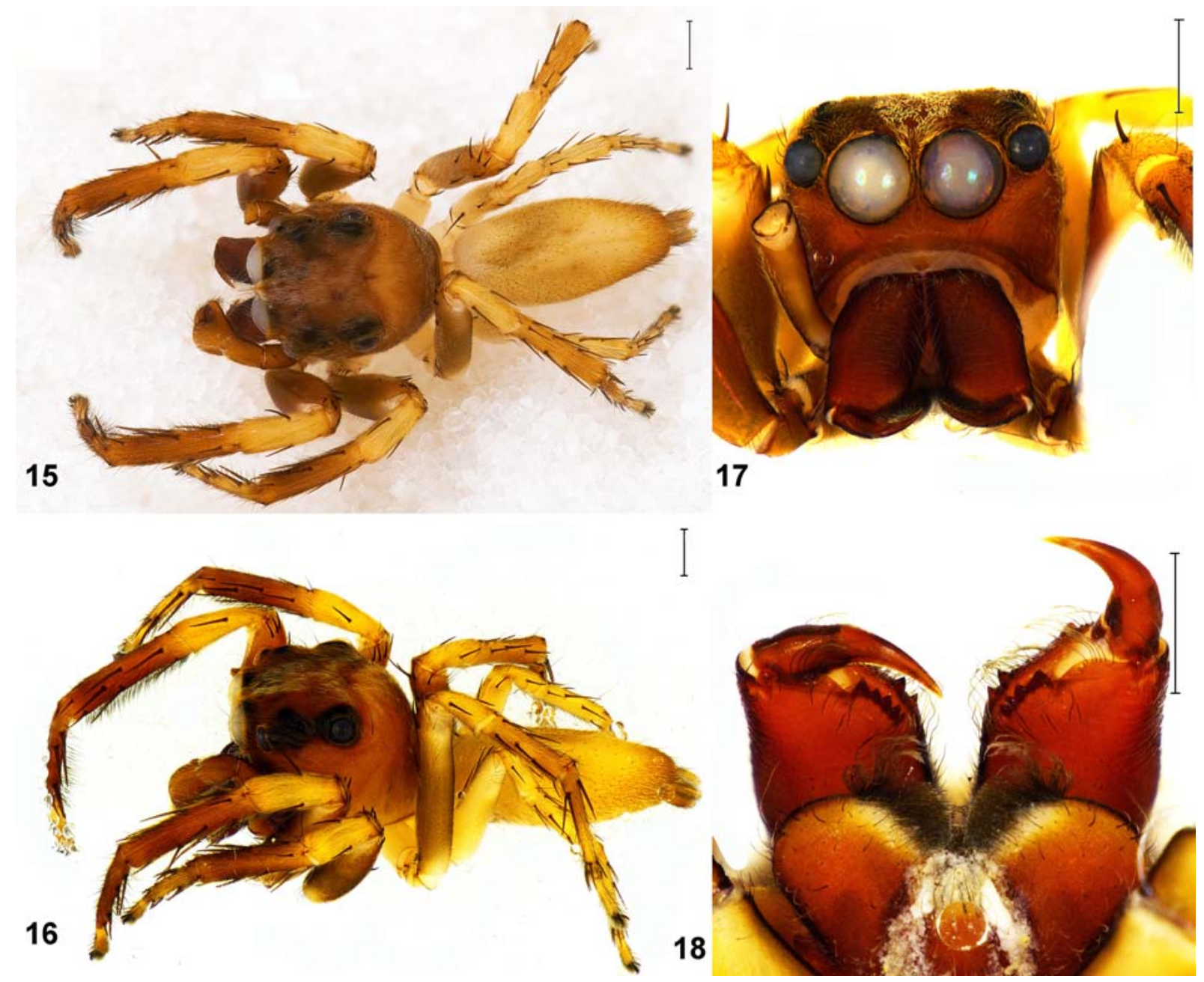

Figs 15-18. Lepidemathis luisae sp.n., O holotype: 15 - habitus, dorsal view; 16 - ditto, lateral view; 17 - ditto, frontal view; 18 - chelicerae, ventral view. Scale bars: $1 \mathrm{~mm}$.

Рис. 15-18. Lepidemathis luisae sp.n., о7 голотип: 15 - габитус, вид сверху; 16 - тоже, вид сбоку; 17 - тоже, вид спереди; 18 - хелицеры, вид снизу. Масштаб: 1 мм.

Genus Lepidemathis Simon, 1903

Lepidemathis: Karsch [1880]; Simon [1899, 1903a]; Prószyński [1987, 2009b]; Żabka [1988]; Zhang, Maddison, [2015].

REMARKS. The genus Lepidemathis is mainly known from the Philippines, with a single record from Vietnam [Prószyński, 2015], and to date comprises three valid species: L. haemorrhoidalis (Simon, 1899), L. unicolor (Karsch, 1880) and the type specis $L$. sericea (Simon, 1899) [WSC, 2015]. Most of the known species are characterized by their gaudy colouration: viz., the body is sometimes clothed with dense and irridescent hairs; the domed prosoma (high and short) orange to brown, with black regions around the eyes and with white lateral setae; the abdomen flat and elongated, with orange to yellowish coloration along the middle line and yellow laterally; legs also yellow. The males have swollen prolateral sides of the palpal tibia, and the prolateral outgrowth on the bulbus. The epigyne with two elongate, white 'win- dows'; the spermathecae compact, with heavily sclerotized globular chambers and very short copulatory ducts situated in the postero-lateral angle of the 'windows'.

\section{Lepidemathis luisae sp.n. \\ Figs 15-21.}

TYPE. Holotype $\sigma^{7}$ (NHMW, 21903) from the Philippines, Samar $\left(11^{\circ} 13.739^{\prime} \mathrm{N}, 125^{\circ} 16.258^{\prime} \mathrm{E}\right), 391 \mathrm{~m}$ a.s.l., hand collecting, 21.04.2012.

ETYMOLOGY. The species is dedicated to the first author's (MF) daugther Luisa Freudenschuss.

DIAGNOSIS. L. luisae sp.n. can be distinguished from its congeners by the conformation of the palp. The new species is most similar to $L$. sericea, from which it can be easily distingushed by the much more pronounced swelling of the prolateral side of palpal tibia, with a huge additional prolateral tibial apophysis and by the wellpronounced prolateral outgrowth of the tegulum. 


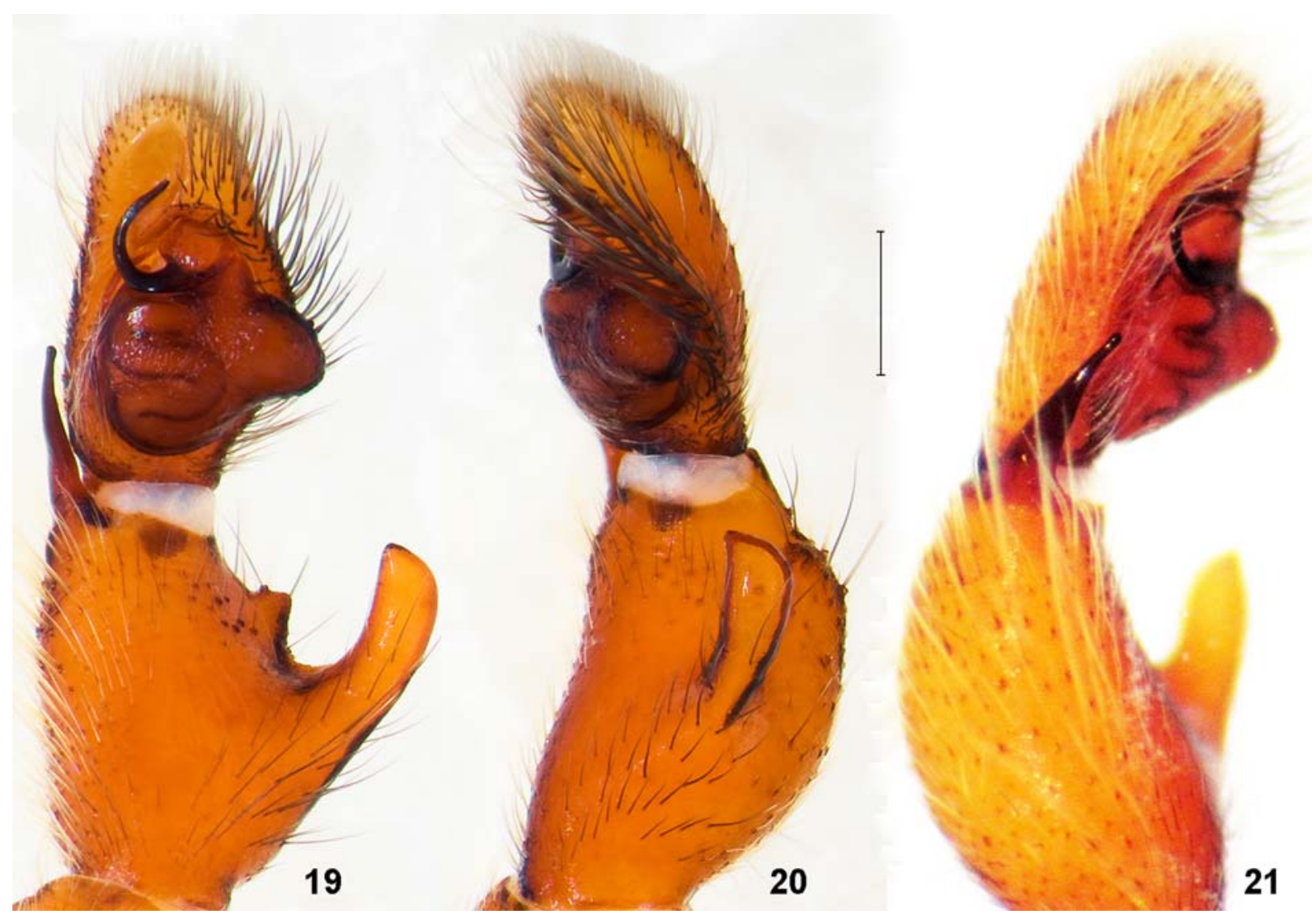

Figs 19-21. Lepidemathis luisae sp.n., $\mathrm{O}^{7}$ holotype: 19 - right palpus, ventral view; 20 - ditto, retrolateral view; 21 - ditto, prolateral view. Scale bar: $0.5 \mathrm{~mm}$.

Pис. 19-21. Lepidemathis luisae sp.n., о голотип: 19 - правая пальпа, вид снизу; 20 - тоже, вид сзади-латерально; 21 тоже, вид спереди-латерально. Масштаб: 0,5 мм.

DESCRIPTION. MALE (holotype). A medium sized species, with the body length of $6.9 \mathrm{~mm}$. Prosoma uniformly coloured in matt orange (coloration in alcohol). The eyes are surrounded by long, partly blackish hairs (the longest ones between AMEs), posterior median eyes and posterior lateral eyes are surrounded by black hairs (Figs 15-17). Chelicera dark orange; retrolateral tooth fissidentate, with five teeth on the left chelicerae and four on the right one (Fig. 18); promarginal tooth pluridentate, arranged as a saw-like blade. Abdomen ventrally orange. Legs orange, but legs I and tarsi, metatarsi and tibiae of legs II dark orange; all legs with long blackish spines. Male palps with the conspicuously long tibia that are uniquely swollen prolaterally and with a unique additional, huge and blunt, apophysis situated at the top of the swelling. The tibial swelling can be compared with that of L. sericea, but the latter lacks an additional apophysis. The retrolateral apophysis prominent, narrow and sharp, as long as the bulbus; the tegulum swollen, with a well-pronounced prolateral outhgrowth (Figs 19-21).

Measurements. Distance between ALEs 1.73; distance between AME to PLE 2.00; distance between PLEs 2.42; prosoma: median length 3.29, width 2.61; abdomen median length 3.61 , width 1.72 ; posterior diameter of eyes 0.52; Pedipalps: TR 0.24, FE 1.38,
PA 0.48, TI 0.86, TA 0.88; Leg I: TR 0.30, FE 0.62, PA 1.46, TI 2.11, ME 1.58, TA 2.17; Leg II: TR 0.26, FE 0.64, PA 1.18, TI 1.81, ME 1.00, TA 1.99; Leg III: TR 0.31, FE 0.89, PA 1.87, TI 1.37, ME 1.01, TA 2.72; Leg IV: TR 0.42, FE 0.87, PA 1.51, TI 1.42, ME 0.64 , TA 2.09

FEMALE Unknown.

DISTRIBUTION. The type locality (Samar, the Philippines) only (Fig. 35).

HABITAT. The collecting locality was situated upstream of Marabut in the primary lowland rainforest. The holotype was collected during a rainy day from the underside of a leaf.

\section{Genus Phaeacius Simon, 1900}

Phaeacius: Thorell [1895]; Simon [1900, 1901a]; Wanless [1981, 1984]; Prószyński [1984]; Wijesinghe [1991]; Barrion, Litsinger [1995]; Jastrzębski [1997]; Peng, Kim [1998]; Zhang, Li [2005]; Prószyński, Deeleman-Reinhold [2010, 2012].

REMARKS. The genus Phaeacius Simon, 1900 contains 13 species distributed from India and Sri Lanka to the Philippines [WSC, 2015]. The type species is $P$. fimbriatus Simon, 1900, which is relatively large in size (up to $11.5 \mathrm{~mm}$ ). Four species are known from the Philippines: P. alabangensis Wijesinghe, 1991; P. canalis Wanless, 1981; P. leytensis Wijesinghe, 1991; and 


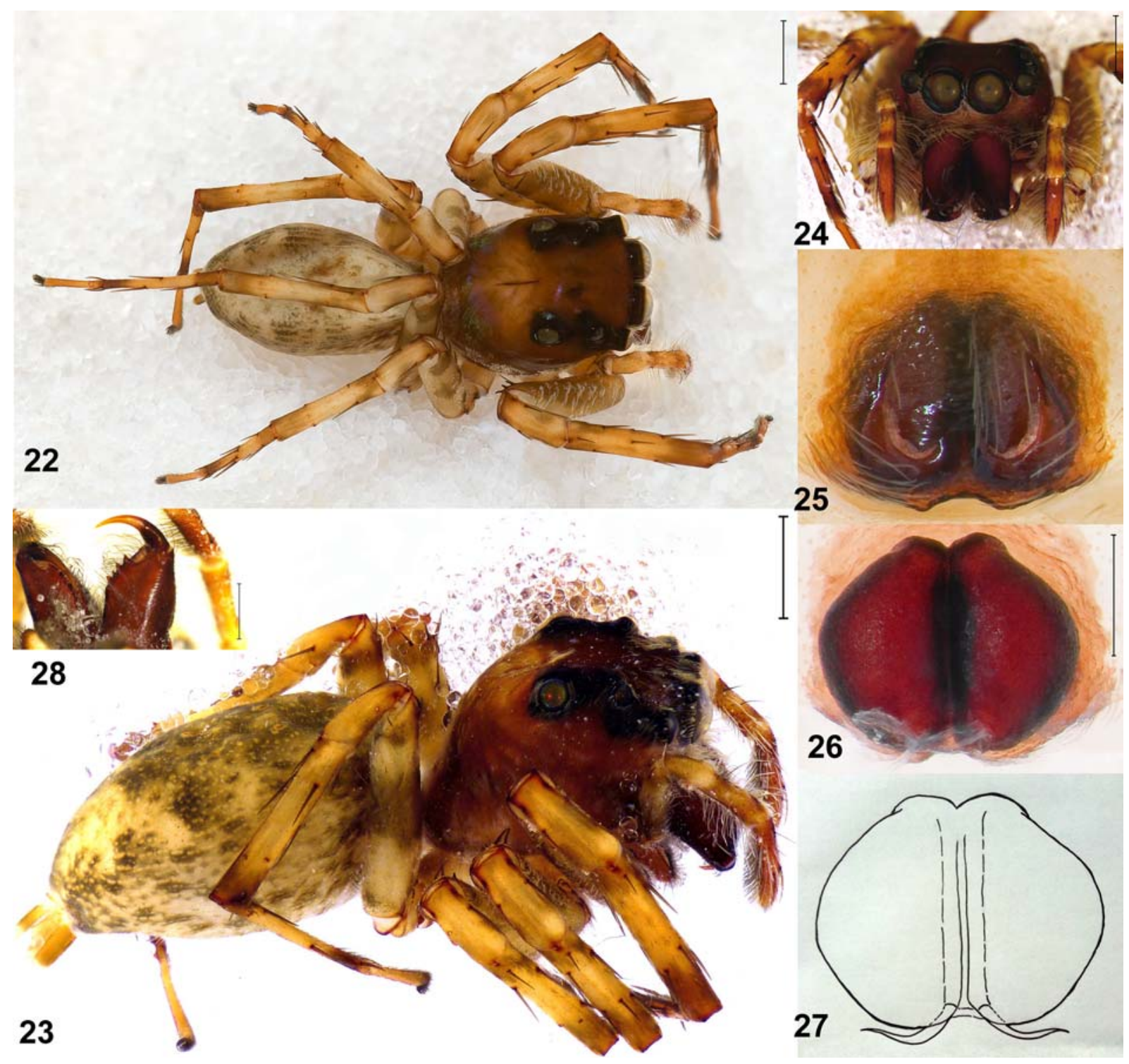

Figs 22-28. Phaeacius hampi sp.n., 9 holotype: 22 - habitus, dorsal view; 23 - ditto, lateral view; 24 - ditto, frontal view; 25 epigyne, ventral view; 26-27 - spermathecae, dorsal view; 28 - chelicerae, ventral view. Scale bars: $1 \mathrm{~mm}(22-24), 0.5 \mathrm{~mm}(25-28)$.

Рис. 22-28. Phaeacius hampi sp.n., + голотип: 22 - габитус, вид сверху; 23 - тоже, вид сбоку; 24 - тоже, вид спереди; 25 эпигина, вид снизу; 26-27 - сперматека, вид сверху; 28 - хелицеры, вид снизу. Масштаб: 1 мм (22-24), 0,5 мм (25-28).

P. mainitensis Barrion et Litsinger, 1995. All the species are very hairy. All are pluridental and characterized by the large posterior median eyes. The prosoma is highly domed, with the torax falling down more or less abruptly behind the lateral eyes. Usually orange to brown in colour, and densly covered with hair. The abdomen is elongated and oval, greyish to yellowish in colour. Legs always bear numerous long and robust spines.

\section{Phaeacius hampi sp.n.}

Figs 22-28.

TYPES. Holotype 9 (NHMW, 21906) from the Philippines, Luzon, Biak Na Bato National Park, Santol cave $\left(15^{\circ} 6.475^{\prime} \mathrm{N}\right.$, $\left.121^{\circ} 4.539^{\prime} \mathrm{E}\right), 16 \mathrm{~m}$ a.s.1., hand collecting, 28. 04.2012. Paratype: 1 ( NHMW, 21907), together with the holotype.

ETYMOLOGY. The specific epithet is a patronym in honor of Heinz Hamp (Pottendorf, Austria), who has supported the second author (MS) during his studies.

DIAGNOSIS. $P$. hampi sp.n. can be distinguished from all its congeners by the size and shape of the epigynal grooves (=atrial lips), which are unique in the genus, stretching along almost the entire length of the epigyne and being completely sclerotized, without membranous parts.

DESCRIPTION. MALE unknown.

FEMALE (holotype). Body length $8.14 \mathrm{~mm}$. The dorsal cephalic region of the prosoma uniformly orange brownish, head region more intensively coloured 
than the thorax, with a short intensive dark brown band pointing to the fovea (this feature is not conspicuous after preservation of the specimen in alcohol). AMEs and ALEs surrounded by fine yellowish scales, PMEs and PLEs surrounded by blackish scales (Figs 22-24). Chelicera dark orange, without notable hairs, retromargin pluridentate, with teeth arranged as a saw-like blade, but very small and poorly visible (Fig. 28). Abdomen dorsally light beige-coloured and with a fine pattern of brownish spots all over the yellow abdomen; spinnerets darker, light brownish. Legs yellow, covered with blackish hairs. Dorsal view of spermathecae shows a pair of large, pear shaped chambers, narrowing anteriorly (Fig. 26). No ducts or accessory glands are visible in dorsal view, being hidden on the ventral side, between the tegument and the spermathecae. By its shape, the epigyne resembles those of other Phaeacius species: the epigynal plate with a pair of large grooves (=atrial lips) separated by a broad and smooth kidneyshaped septum. The grooves are unique in this species, stretching almost all over the entire length of epigyne and being markedly sclerotized, without membranous parts. The posterior parts of the grooves form deep copulatory openings (Figs 26-27).

Measurments. Female holotype: distance between ALEs 1.55; distance between AME to PLE 1.89; distance between PLEs 2.09; prosoma: median length 3.67, width 2.64; abdomen median length 4.47, width 2.66; posterior diameter of eyes 0.54 ; pedipalps: TR 0.21 , FE 0.54, PA 0.33, TI 0.31, TA 0.43; Leg I: TR 0.34, FE 1.57, PA 0.84, TI 1.24, ME 0.86, TA 0.57; Leg II: TR 0.49, FE 1.01, PA 0.99, TI 0.92, ME 0.59, TA 0.28; Leg III: TR 0.40, FE 2.38, PA 0.98, TI 0.19, ME 0.20, TA 0.67; Leg IV: TR 0.32, FE 0.42, PA 0.48, TI $0.61, \mathrm{ME} 1.13$, TA 0.51; Female paratype: distance between ALEs 1.52; distance between AME to PLE 1.84; distance between PLEs 2.12; prosoma: median length 3.56 , width 2.66; abdomen median length 4.51 , width 2.69; posterior diameter of eyes 0.50 ; pedipalps: TR 0.20, FE 0.58, PA 0.38, TI 0.30, TA 0.47; Leg I: TR 0.37, FE 1.49, PA 0.90, TI 1.24, ME 0.89, TA 0.59; Leg II: TR 0.53, FE 1.09, PA 1.03, TI 0.98, ME 0.59, TA 0.26; Leg III: TR 0.46, FE 2.36, PA 0.99, TI 0.22, ME 0.23, TA 0.71; Leg IV: TR 0.30, FE 0.41, PA 0.47, TI 0.67, ME 1.16, TA 0.51.

DISTRIBUTION. The type locality (Santol cave within the Biak Na Bato National Park in Luzon, Philippines) only (Fig. 35).

HABITAT. The Biak Na Bato National Park is situated in a carst limestone massif, with numerous small caves and stony plates close to the earth surface. The specimens were found sitting on leaves beside a trail in a sunny spot.

Genus Phintella Strand in Bösenberg et Strand, 1906

REMARKS. The genus is characterized by its small size and slender body, with gray to brown coloration. The abdomen often with light and dark tranverse bands, or sometimes pale with gray linear patterns made of adpressed setae/scales. Males have a simple palpal structure, with the single tibial apophysis. Females have simple spermathecae.

$P$. piatensis Barrion et Litsinger, 1995 was described on the basis of three adult females and one spiderling (collected in 1981/82) by Barrion, Litsinger [1995]. The type locality is Piat village in Cagayan province (Luzon). The male collected by us shares the following features with the female types: a very similar body coloration, viz., the prosoma bright light brown, with its cephalic region bearing a light beige-coloured transverse band. The chelicerae of the studied male are long, light brown and unidentate, with two promarginal teeth and one retromarginal teeth. The studied male can be distinguished from that of $P$. bunyiae Barrion et Litsinger, 1995 by the dorsal abdominal pattern and by its distribution (the Panay Island). Therefore, we are confident that the studied male indeed belongs to $P$. piatensis and therefore have provisionally described it below under this name. A final solution of the sex matching in this species will be possible when both sexes are collected together from the same habitat.

\section{Phintella piatensis Barrion et Litsinger, 1995} Figs 29-34.

MATERIAL. PHILIPPINES: $1 \sigma^{7}$ (NHMW, 21908), Luzon, Biak Na Bato National Park, Santol cave $\left(15^{\circ} 06.475^{\prime} \mathrm{N}\right.$, $\left.121^{\circ} 04.539^{\prime} \mathrm{E}\right), 16 \mathrm{~m}$ a.s.1., hand-collecting, 28.04.2012.

DIAGNOSIS. The male of $P$. piatensis can be distinguished from those of other Phintella species by the conformation of the palp. It is most close to $P$. aequipeiformis Żabka, 1985 from Vietnam, from which it can be readily distinguished by the following characters: the embolic shape more swollen and more curved retrolaterally; the tegulum straight rather than curved; the retrolateral tibial apophysis almost as long as wide at its base, directed anteriad; and the tibial apophysis much shorter and wider than that of $P$. aequipeiformis.

DESCRIPTION. MALE. Body length $4.94 \mathrm{~mm}$. Prosoma bright light brown, with black around eyes. AMEs surrounded by long white hairs and wirth a small bunch of longer hairs above them; PMEs surrounded by longer white hairs. The cephalic region of the prosoma bears a light beige transverse band (Figs 29-31). Chelicera long and light brown, unidentate, with two promarginal teeth and one retromarginal tooth (Fig. 34). Abdomen elongated; dorsally white to yellow, with a blackish pattern; ventrally with a black dot in front of the spinnerets. Spinnerets white to yellow. Legs darker, FE, ME and TR of legs III and IV of the same colour as the prosoma. Bulbus oblong and narrow, with a spur-like projection seen in the lateral view (Fig. 33). The retrolateral tibial apophysis short, directed ventro-anteriad (Figs 32-33).

Measurements. Distance between ALE 1.64; distance between AME to PLE 1.17; distance between PLE 1.62; prosoma: median length 2.35, width 1.79; abdomen median length 2.59 , width 1.53 ; posterior diameter of eyes 0.42 ; pedipalps: TR 0.18 , FE 0.56 , 


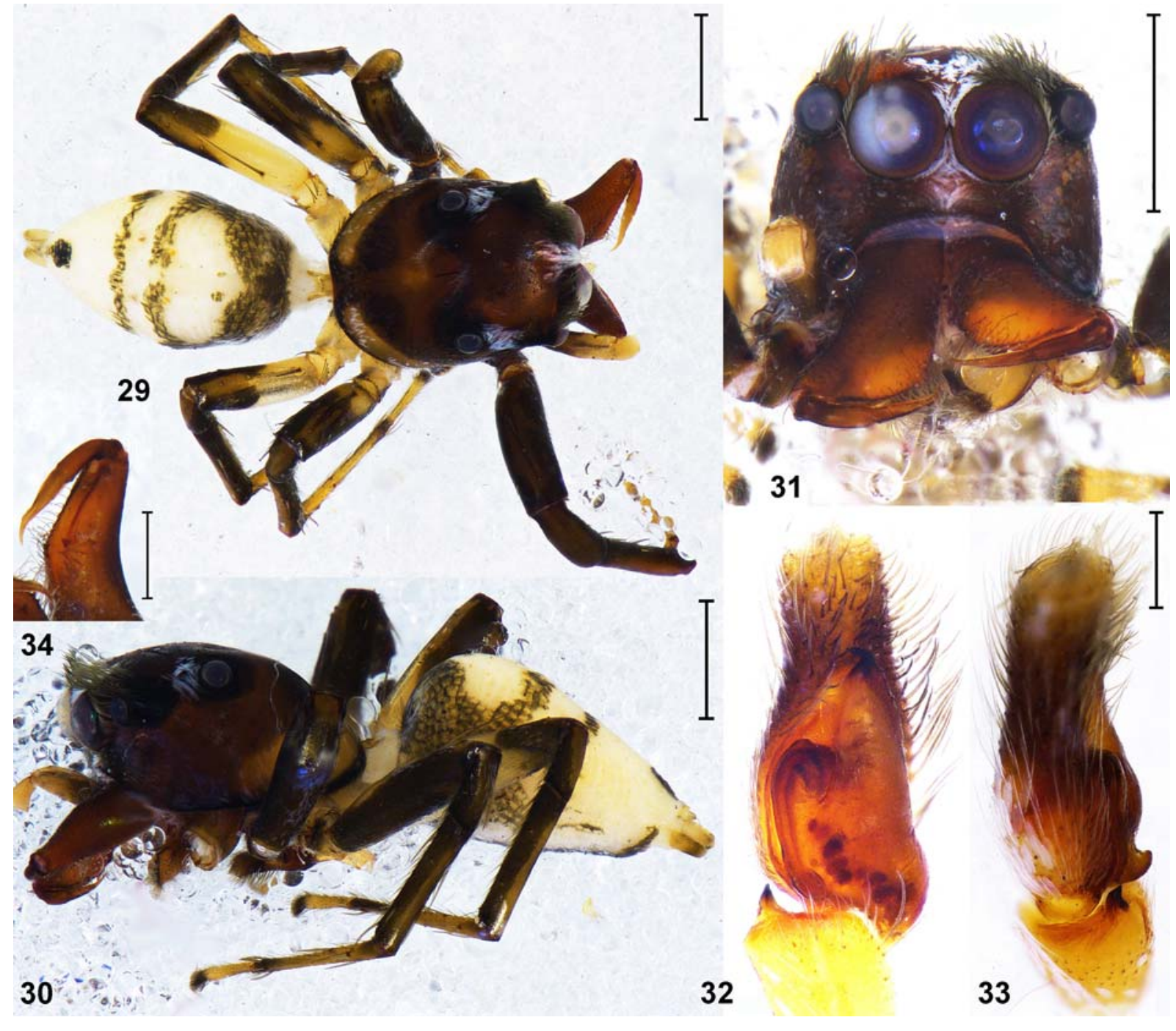

Figs 29-34. Phintella piatensis Barrion et Litsinger, 1995, $0^{7}: 29$ - habitus, dorsal view; 30 - ditto, lateral view; 31 - ditto, frontal view; 32 - right palpus, ventral view; 33 - ditto, prolateral view; 34 - left chelicera, ventral view. Scale bars: $1 \mathrm{~mm}(29-31)$, 0.1 mm (32-33), $0.5 \mathrm{~mm}(34)$.

Рис. 29-34. Phintella piatensis Barrion et Litsinger, 1995, o’: 29 - габитус, вид сверху; 30 - тоже, вид сбоку; 31 - тоже, вид спереди; 32 - правая пальпа, вид снизу; 33 - тоже, вид сзади-латерально; 34 - левая хелицера, вид снизу. Масштаб: 1 мм (2931), 0,1 мм (32-33), 0,5 мм (34).

PA 0.28 , TI 0.25 , TA 0.76 ; Leg I: TR 0.33 , FE 1.23, PA 0.62, TI 1.14, ME 1.27, TA 0.5; Leg II: TR 0.27, FE 1.6, PA 0.59, TI 1.33, ME 1.31, TA 0.51; Leg III: TR 0.33, FE 1.62, PA 0.62, TI 1.2, ME 1.47, TA 0.56; Leg IV: TR 0.25, FE 1.6, PA 0.37, TI 1.2, ME 1.55, TA 0.51 .

FEMALE. See Barrion, Litsinger [1995].

DISTRIBUTION. The species is known from the type locality Piat Village in Luzon [Barrion, Litsinger, 1995], and Santol cave within the Biak $\mathrm{Na}$ Bato National Park in Luzon, the Philippines (Fig. 35).

HABITAT. The Biak Na Bato National Park is situated in a carst limestone massif with numerous small caves and stony plates close to the earth surface. The specimen was collected from a leaf in a sunny spot beside a trail.

\section{Discussion}

Many other salticid species were found during our field trip and some of them represent either the first records for the Philippines, or the first Philippine records with exact localities. All salticid specimens were handcollected in April 2012 and are depostied in the NHMW (see Table). Hasarius adansoni Audouin, 1826 is a cosmopolitan species, and Menemerus bivittatus (Dufour, 1831) — a pantropcial species; both are known from many countries around the world [Audouin, 1826; Dufour, 1831; WSC, 2015]. Despite this, for both species we have presented here the first Philippine records with exact localities (see Table). The specimens of $H$. adansoni were collected from the middle of the capital city in a small park, in the historic district Ermita close 
New Salticidae from the Philippines

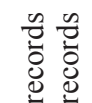

害

言

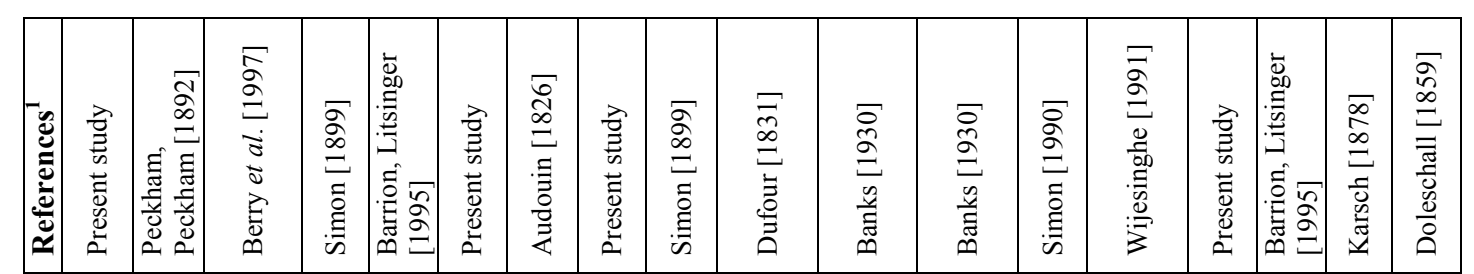

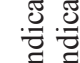

党

-

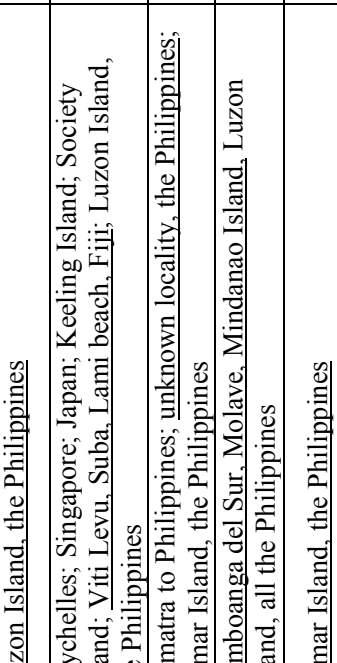

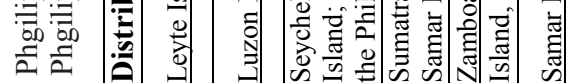

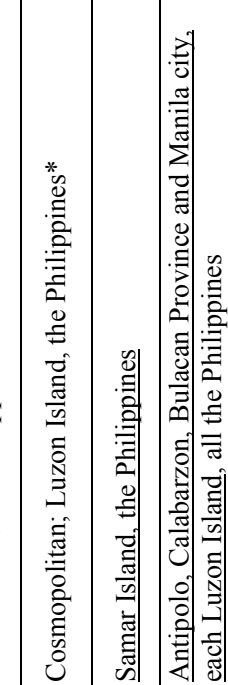

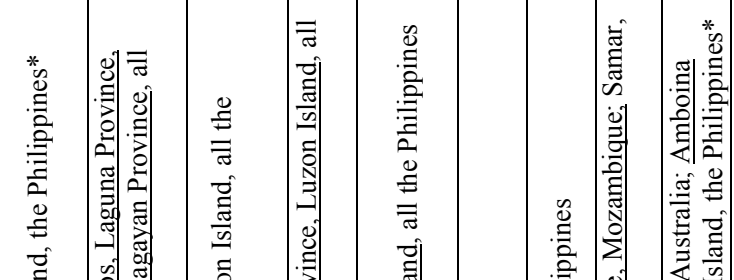

五

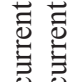

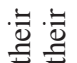

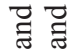

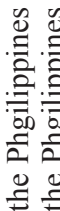

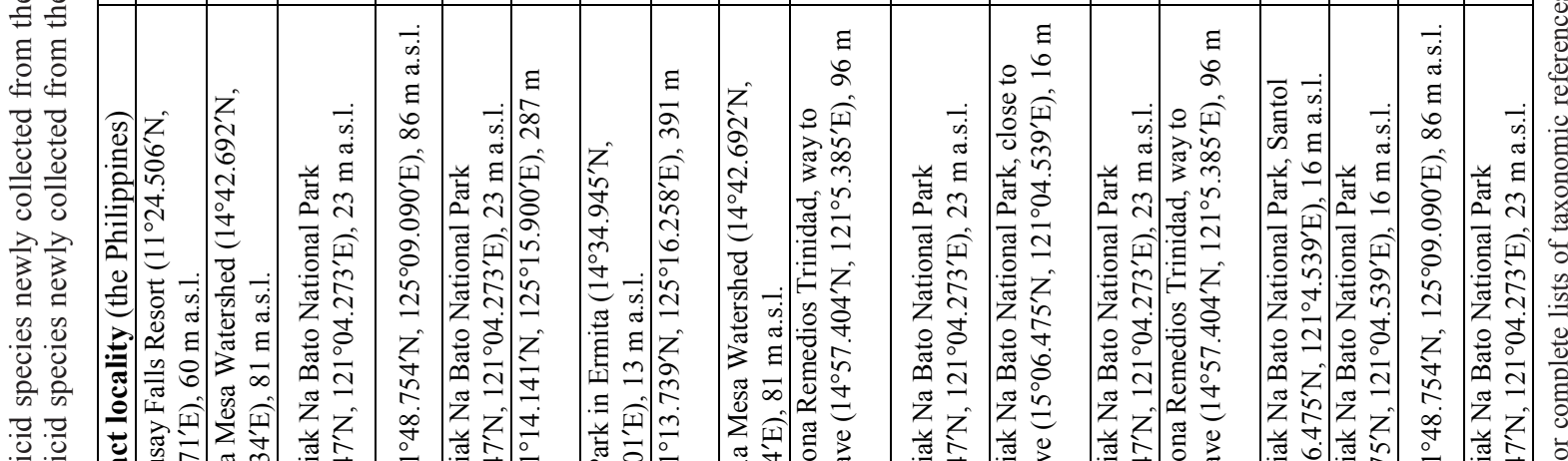

$\rightarrow$

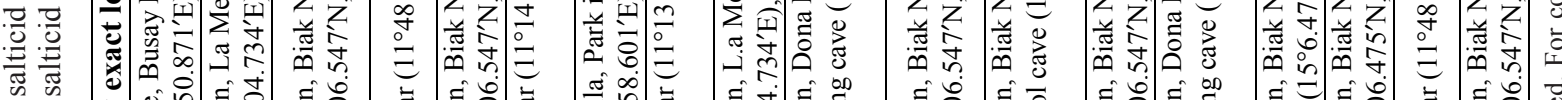

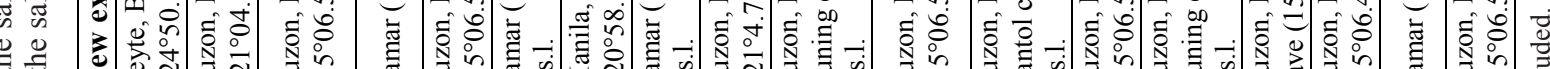

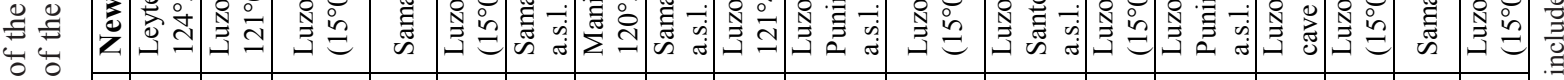

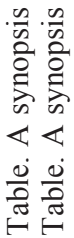

总

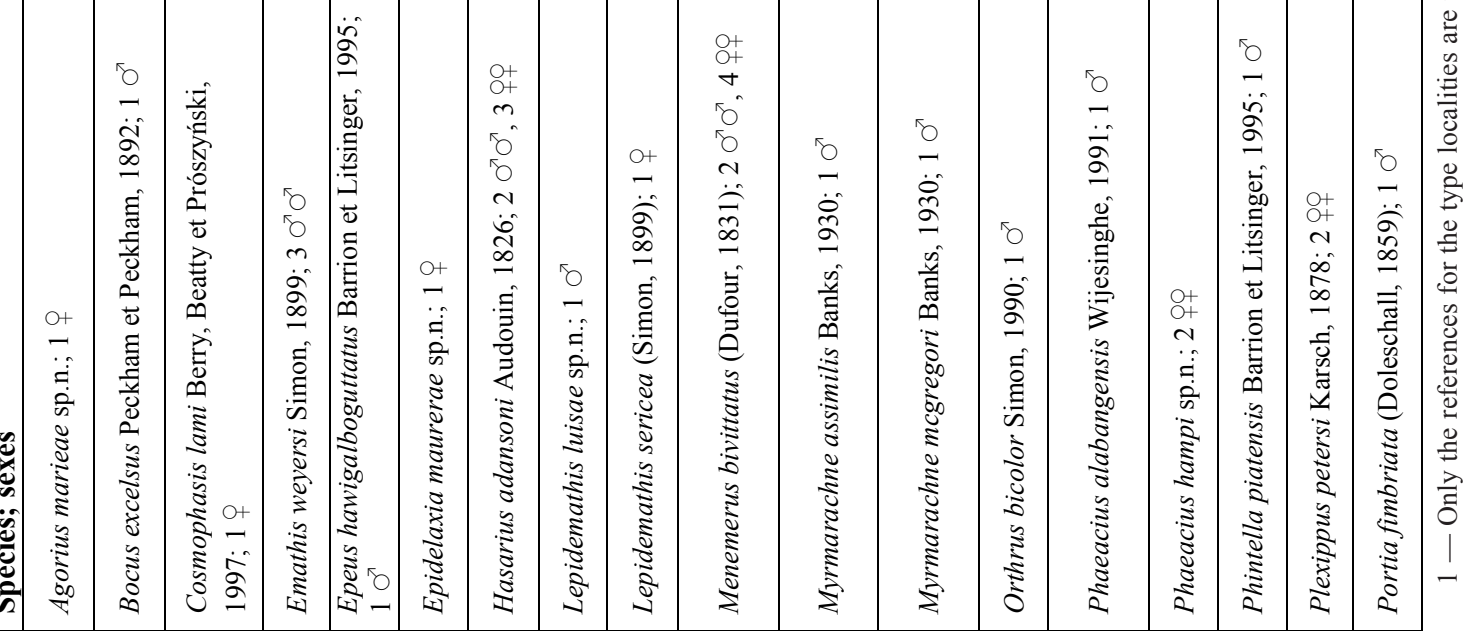


to the sea. The specimens were found sitting on a wall in a shady place. M. bivittatus was collected from Dona Remedios Trinidad, which lies on the way to the Puning cave in Luzon. It is a hilly area with dense vegetation. The specimens were found sitting on dry palm leaves on the street close to the village. Another new first record is Portia fimbriata (Doleschall, 1859), which was hitherto known from the type locality on Amboina (Ambon) Island, Moluccas and from Nepal, India, Sri Lanka, Taiwan to Australia [Doleschall, 1859; WSC, 2015]. Here we present a new record for $P$. fimbriata from Biak Na Bato National Park in Luzon Island, the Philippines. The Biak Na Bato National Park is situated in a carst limestone massif with numerous small caves and stony plates on the ground. The specimens were found on bushes close to a small trail along the main path. See Table for further details on the exact localities of other species.

ACKNOWLEDGMENTS. First, we are greatly indebted to Jerzy Prószyński (Museum and Institute of Zoology, Warsaw, Poland) for his kind and continuous support of our studies and for providing us with useful literature. We also wish to thank G.B. Edwards (Florida State Collection of Arthropods, Florida, USA) for productive discussion of numerous taxonomic matters regarding Salticidae. Our sincere thanks go to Gustavo Ruiz (Instituto Butantan, Brazil) and anonymous referees for detailed reviewing the ms. Finally, Christoph Hörweg (NHMW) is acknowledged for giving us access to the microscopy facilities and Jason Dunlop (ZMHB, Germany) for providing us with the comparative material.

\section{References}

Audouin V. 1826. Explication sommaire des planches d'arachnides de l'Egypte et de la Syrie // Description de 1'Egypte, ou recueil. Histoire Naturelle. Vol.1. No.4. P.99-186.

Badcock A.D. 1918. Ant-like spiders from Malaya collected by the Annandale-Robinson Expedition 1901-02 // Proceedings of the Zoological Society of London. Vol.917. P.277-321.

Banks N. 1930. Ant-like spiders of the genus Myrmarachne from the Philippines // Psyche. Vol.37. P.207-217.

Barrion A.T., Litsinger J.A. 1995. Riceland Spiders of South and Southeast Asia. Wallingford, England: CAB International. XIX. $736 \mathrm{pp}$.

Berry J.W., Beatty J.A., Prószyński J. 1997. Salticidae of the Pacific Islands. II. Distribution of nine genera, with descriptions of eleven new species // Journal of Arachnology. Vol.25. P.109136.

Bösenberg W., Strand E. 1906. Japanische Spinnen // Abhandlungen der Senckenbergischen naturforschenden Gesellschaft. Bd.30. S.93-422.

Dufour L. 1831. Descriptions et figures de quelques Arachnides nouvelles ou mal connues et procédé pour conserver à sec ces Invertébrés dans les collections // Annales des Sciences Naturelles, Zoologie, Paris. Vol.22. P.355-371.

Doleschall L. 1859. Tweede Bijdrage tot de Kenntis der Arachniden van den Indischen Archipel // Acta Societatis Scientiarum Indica-Neerlandica. Vol.5. P.1-60.

Edmunds M., Prószyński J. 2001. New species of Malaysian Agorius and Sobasina (Araneae: Salticidae) // Bulletin of the British Arachnological Society. Vol.12. P.139-143.

Edwards G.B. 2015. Freyinae, a major new subfamily of Neotropical jumping spiders (Araneae: Salticidae) // Zootaxa. Vol.4036. No.1. P.1-87.
Forster L.M. 1982. Vision and prey-catching in jumping spiders // American Scientist. Vol.70. P.165-175.

Jastrzębski P. 1997. Salticidae from the Himalayas. Subfamily Spartaeinae Wanless, 1984 (Araneae: Salticidae) // Genus. Vol.8. No.3-4. P.701-713.

Karsch F. 1878. Übersicht der von Peters in Mossambique gesammelten Arachniden // Monatsberichte der Königlich Preussischen Akademie der Wissenschaften zu Berlin. Bd.1878. S.314-338.

Karsch F. 1880. Arachnologische Blätter (Decas I) // Zeitschrift für die Gesammten Naturwissenschaften. Bd.5. S.373-409.

Logunov D.V. 1999. Redefinition of the genus Habrocestoides Prószyński, 1992, with establishment of a new genus Chinattus gen. n. (Araneae: Salticidae) // Bulletin of the British Arachnological Society. Vol.11. Pt.4. P.139-149.

Maddison W.P. 2015. A phylogenetic classification of jumping spiders (Araneea: Salticidae) // Journal of Arachnology. Vol.43. P.231-292.

Metzner H. 1999. Die Springspinnen (Arachnida, Araneae, Salticidae) Griechenlands // Andrias. Bd.14. S.1-279.

Metzner H. 2015. Jumping spiders (Arachnida: Araneae: Salticidae) of the world; online at: http://www.jumping-spiders.com (accessed on 24.12.2015).

Murphy F., Murphy J. 2000. An Introduction to the Spiders of Southeast Asia. Malaysian Nature Society. Kuala Lumpur. $625 \mathrm{pp}$.

Peckham G.W., Peckham E.G. 1892. Ant-like spiders of the family Attidae // Occasional Papers of the Natural History Society of Wisconsin. Vol.2. No.1. P.1-84.

Peng X.J., Kim J.P. 1998. Four species of jumping spiders (Araneae: Salticidae) from China // Korean Journal of Biological Sciences. Vol.2. P.411-414.

Prószyński J. 1968. Redescriptions of type-species of genera of Salticidae (Araneida). IV-V // Annales Zoologici, Warszawa. T.26. P.217-225.

Prószyński J. 1984. Atlas rysunków diagnostycznych mniej znanych Salticidae (Araneae). Siedlce: Wyższa Szkola Rolniczo-Pedagogiczna. Vol.2. P.1-177.

Prószyński J. 1987. Atlas rysunków diagnostycznych mniej znanych Salticidae 2. Siedlce: Zeszyty Naukowe Wyższej Szkoly Rolniczo-Pedagogicznej. P.1-172.

Prószyński J. 1992. Salticidae (Araneae) of India in the collection of the Hungarian National Natural History Museum in Budapest // Annales Zoologici Warszawa. T.44. P.165-277.

Prószyński J. 2009a. Comments on the Oriental genera Agorius and Synagelides (Araneae: Salticidae) // Makarov S.E., Dimitrijeviæ R.N. (eds.) Advances in Arachnology and Developmental Biology. Institute of Zoology, Bulgarian Academy of Sciences Monographs. Vol.12. P.311-325.

Prószyński J. 2009b. Redescriptions of 16 species of Oriental Salticidae (Araneae) described by F. Karsch, E. Keyserling and C.L. Koch, with remarks on some related species // Arthropoda Selecta. Vol.18. No.3-4. P.153-168.

Prószyński J. 2015. Monograph of Salticidae (Araneae) of the World (1995-2015); online at: http://www.peckhamia.com/salticidae (accessed on 30.06.2015).

Prószyński J., Deeleman-Reinhold C.L. 2010. Description of some Salticidae (Araneae) from the Malay archipelago. I. Salticidae of the Lesser Sunda Islands, with comments on related species // Arthropoda Selecta. Vol.19. P.153-188.

Prószyński J., Deeleman-Reinhold C.L. 2012. Description of some Salticidae (Aranei) from the Malay archipelago. II. Salticidae of Java and Sumatra, with comments on related species // Arthropoda Selecta. Vol.21. P.29-60.

Simon E. 1877. Etudes arachnologiques. 5e Mémoire. IX. Arachnides recueillis aux îles Phillipines par MM. G. A. Baer et Laglaise // Annales de la Société Entomologique de France. T.7. P.53-96.

Simon E. 1899. Contribution à la faune de Sumatra. Arachnides recueillis par M. J. L. Weyers, à Sumatra. (Deuxiéme mémoire) // Annales de la Société Entomologique de Belgique. T.43. P.78-125.

Simon E. 1900. Etudes arachnologiques. 30e Mémoire. XLVII. Descriptions d'espèces nouvelles de la famille des Attidae // 
Annales de la Société Entomologique de France. T.69. P.2761

Simon E. 1901a. Histoire naturelle des araignées. Paris. Vol.2. P.381-668.

Simon E. 1901b. Descriptions d'arachnides nouveaux de la famille des Attidae (suite) // Annales de la Société Entomologique de Belgique. T.45. P.141-161.

Simon E. 1902. Descriptions d' Arachnides nouveaux de la famille des Salticidae (Attidae) // Ann. Soc. Ent. Belg. T.46. P.24-54, 363-406.

Simon E. 1903a. Histoire naturelle des araignées. Paris. Vol.2. P.669-1080.

Simon E. 1903b. Etudes arachnologiques. 34e Mémoire. LIV. Arachnides recueillis à Sumatra par M. J. Bouchard // Annales de la Société Entomologique de France. T.72. P.301-310.

Szüts T. 2003. New species of Agorius Thorell, 1877 (Araneae: Salticidae) from New Guinea // Acta Zoologica Academiae Scientiarum Hungaricae. Vol.49. P.61-69.

Thorell T. 1877. Studi sui Ragni Malesi e Papuani. I. Ragni di Selebes raccolti nel 1874 dal Dott. O. Beccari // Annali de Museo Civico di Storia Naturale di Genova. Vol.10. P.341-637.

Thorell T. 1895. Descriptive catalogue of the spiders of Burma, London. 406 pp.
Wanless F.R. 1981. A revision of the spider genus Phaecius (Araneae: Salticidae) // Bulletin of the British Museum of Natural History (Zool.).Vol.41. P.199-212.

Wanless F.R. 1984. A review of the spider subfamily Spartaeinae nom. n. (Araneae: Salticidae) with descriptions of six new genera // Bulletin of the British Museum of Natural History (Zool.). Vol.46. P.135-205.

Wijesinghe D.P. 1991. New species of Phaeacius from Sri Lanka, Sumatra and the Philippines (Araneae: Salticidae) // Bulletin of the British Arachnological Society. Vol.8. P.249-255.

WSC 2015. World Spider Catalog. Natural History Museum Bern, version 16.05; online at: http://wsc.nmbe.ch (accessed on 24.12.2015).

Żabka M. 1988. Salticidae (Araneae) of Oriental, Australian and Pacific regions, III // Annales Zoologici, Warszawa. Vol.41. P.421-479.

Zhang J.X., Li D.Q. 2005. Four new and one newly recorded species of the jumping spiders (Araneae: Salticidae: Lyssomaninae \& Spartaeinae) from (sub)tropical China // The Raffles Bulletin of Zoology. Vol.53. P.221-229.

Zhang J.X., Maddison W.P. 2015. Genera of euophryine jumping spiders (Araneae: Salticidae), with a combined molecular-morphological phylogeny // Zootaxa. Vol.3938. No.1. P.1-147.

Responsible editor D.V. Logunov 